\title{
A double exile: Filipino settlers in the outer Torres Strait islands, $1870 \mathrm{~s}-1940 \mathrm{~s}^{1}$
}

\author{
Anna Shnukal
}

Surprisingly little has been published about the early Filipinos in northern Australia and their relationships with local Indigenous people, compared with their Japanese, Indonesian and even Chinese contemporaries. ${ }^{2}$ Despite their origins in the 19th-century marine industries, each community manifests different characteristics, composition and historical trajectories. Examining the similarities and differences among them sheds light on early Australian history and the role played by government policy and powerful individuals in regions far from centres of power and poorly served by communications. The early Filipinos of Broome and Darwin were in general more socially and legally constrained and hence relatively less prosperous than the Filipinos of Torres Strait. Most of the latter lived on Thursday Island, the regional commercial centre, while others established majority Filipino communities on adjacent Horn Island (from 1889) and Hammond Island (from 1929). The subject of this article, however, is the small group who chose to live for an extended period on the outer (more remote) islands with their Torres Strait Islander wives and children and were thus doubly exiled - both from their homeland and the Filipino communities of Thursday and Horn Islands. It also examines the link between ancestral identity and land, arguably the topic of most interest to their descendants, and demonstrates the tenuousness of land claims made by contemporary Torres Strait Islanders of Filipino descent on the sole basis of orally-transmitted accounts of land acquisition.

'Exile' denotes prolonged absence from one's native land or former community; it may connote forceful expulsion, nostalgia or regret but this is not its core definition, otherwise one could not refer to 'voluntary exile' for economic, political, social, religious, artistic, even financial reasons (witness the wealthy United Kingdom 'tax-exiles' of the 1970s). For Australian writer, Kate Jennings, and others of her generation, the experience of 'exiling ourselves - it was more

1 Sources for this paper include the Somerset and Cooktown registers of births, deaths and marriages; Missionaries of the Sacred Heart register of baptisms 1884-1894; Murray Island register of births, deaths and marriages 1885-1961; alien registration cards 1916-1917; Queensland Department of Native Affairs correspondence; Thursday Island court records; tombstone inscriptions, divers' registers, newspaper reports and Torres Strait field research notes from interviews 1980-2010.

2 See, however, Austin 1992; Chase 1981; Cubillo-Carter 2000; Hennessy 2004; Ileto 1993, 2004; Nailon 2005a, 2005b; Nailon and Huegel 2001; Puertollano 2008; Ruiz Wall and Hunt 2008; Shnukal 2004. 
serious than expatriation - was one of gain, of wholeness' ${ }^{3}$ The Filipinos under discussion were 'self-exiles', both 'pushed' by endemic poverty and 'pulled' by economic, social and political opportunities to seek their individual destinies in the strait.

Those who settled in the outer islands chose their double exile for personal reasons, yet they shared with their countrymen those social and psychological characteristics that bind a group together. Although not a culturally homogeneous or cohesive group, the Filipinos were perceived as such in Australia: they came from similar island backgrounds, their ages, physical appearance, education and economic interests were similar, as were their understandings, values, prejudices and ideals. Their islands were distant colonial outposts of the Spanish empire; the islands they found were distant colonial outposts of the British empire. Spanish rule bestowed Spanish names, a lingua franca and a deep Catholic belief; and as Christians, they were an anomaly among the strait's Asian communities, ${ }^{4}$ although this did not lessen the prejudice of the European Protestant majority. Whatever their differences, the Filipinos recognised their mutual bonds as 'countrymen' and their lives were as intertwined at sea as on shore: they lived cheek by jowl both on the boats and in the cottages and boarding houses of Thursday Island. Almost all of them continued to work in some capacity in marine occupations until physically unable to do so.

\section{Filipinos in the Torres Strait marine industries}

Filipino seamen arrived in Western Australia to join its pearl rush from the late 1860s, moving across northern Australia as opportunities arose. Payable quantities of pearlshell gathered on Warrior Reef in early 1870 set the Torres Strait industry in train but, as in Western Australia, it depended to a large extent on unskilled, local Indigenous 'swimming divers', who took shell from shallow waters or reefs close to shore. A few years later the industry was transformed by adoption of the divers' dress: corselet, helmet and air hose. Divers could now descend to previously inaccessible depths in search of more productive beds and diving was no longer a minimally-skilled, individual occupation but a far more hazardous and uncertain undertaking. The rewards for experienced divers and tenders were prestige and high wages, almost comparable with Europeans, and far outstripping those of ordinary boat crews.

From the late 1870s mass indenture began to replace individual recruitment and large numbers of seaman signed shipping agreements in Asian ports for terms of between 18 months and three years. Pearling provided the impetus for Thursday Island's development and supported its various businesses either directly or indirectly. As a resource-based industry, it was hostage to volatile prices in an

3 Jennings 2010: 24 .

4 A small number of adult Japanese became Anglicans from the mid-1890s, the early converts being instructed by the honorary catechist, Taira Kashiwagi, until his departure from Thursday Island in c1912. In time, many locally-born children of Japanese and Indonesian heritage also became Christians. 
overseas market it could not control, the constant pressure of shell bed depletion and, equally, the serendipitous discovery of fresh fields. The Filipino population fluctuated in line with demand for shell, external forces determining the mass movements of Filipinos to other parts of north Australia, New Guinea, Dutch East Indies or back to the Philippines.

The first enumeration of the Torres Strait Filipino population was made in 1884 by the newly-arrived Catholic priest, who found 'about forty Filipinos' living on Thursday Island and 'about four hundred Catholics from Manila scattered amongst the various islands. They were there fishing for pearls' ${ }^{5}$ The following decade marked the height of Filipino participation in the marine industries but by the mid-1890s Filipinos without strong ties to Australia were beginning to leave the region, particularly after the introduction of restrictive race-based legislation from 1901. Overseas markets for shell collapsed in 1905 and again during the First World War.

1912 was the last year in which Filipinos were employed as divers and personsin-charge in Torres Strait. They comprised around 20 per cent of the total between 1895 and 1898, with a slow decline from 1898 to 1901. The fleets with their Filipino divers and crews left depleted Torres Strait for the Dutch Aru Islands in 1905; others moved to Darwin, Broome and the New Guinea coast and thereafter Filipinos declined precipitously both in numbers and as a proportion of the total workforce. By contrast, the Japanese increased their participation to the point where, in 1906, they completely dominated the industry and continued to do so until the Second World War. ${ }^{6}$

As marine industry profitability rose and fell and the Filipinos' finances, physical capacities and family circumstances changed, they alternated between the more capital-intensive pearling industry and the less capital-intensive bêche-de-mer (trepang), trochus and tortoiseshell industries. During the 1880s and early 1890s they gained a reputation for raiding Cape York mainland camps for labour, abducting women and illegally employing Aboriginal men without signing them on articles. In response to these well-documented abuses and the disease and violent reprisals that followed, the government implemented a series of laws and regulations to constrain the activities of 'coloured men', including blameless Filipinos who fished from their small cutters along the coast of Cape York with their wives and children, taking on their affinal kinfolk as seasonal labour. The most significant was the Aboriginals Protection and Restriction of the Sale of Opium Act 1897 and later amendments, which made it illegal to carry locally-born women or minors on boats, no matter what their relationship was to the owner. The Pearl-shell and Bêche-de-Mer Fishery Acts Amendment Act 1898 prohibited nonBritish subjects from renting or purchasing boats; the Immigration Restriction Act 1901 prevented them from bringing younger relatives and countrymen to Australia; and The Aboriginals Protection Act 1901 placed restrictions on marriages

5 Dupeyrat 1935: 68

6 Bach 1955: 279. 
between Indigenous women and non-Indigenous men. These laws, however, were insufficient in the eyes of the local European shellers, who called for even more stringent legislation to curb 'alien' employment of Aboriginal people.

\section{Marriages}

The marriage and naturalisation patterns of early Filipinos (and to some extent Indonesians) in Torres Strait are unique among its Asian communities, in that they contracted many stable unions with local Indigenous women and were encouraged to become naturalised by the then government resident, John Douglas, who wrote approvingly that they were 'the only Asiatic people who have become thoroughly domesticated among us. When they have made a little money, they send an order home for a wife; they then marry, beget children, and frequently become naturalised'. ${ }^{7}$ A man's choice of wife - based on his individual values, personal aspirations and economic circumstances - was, in hindsight and based on his Australian-born descendants' biographies, the chief determinant of their fate until the 1970s.

Contemporary documentation of the earliest unions between Filipino men and local Indigenous women is fragmentary, since Catholic marriages were not performed on Thursday Island until October 1884 and only legal marriages were registered. Vital registration and baptismal data also provide evidence of a few unmarried couples and their offspring, as do tombstones and incidental details in court documents. From this admittedly incomplete record, I have identified 20 Filipino men with Cape York Aboriginal partners and 40 with Torres Strait Islander partners. Judging from the names and birthplaces of the Aboriginal women, many of them were related and they, their children and their extended kinfolk were crucial to the success of the men's fishing enterprises, fetching water and wood from the mainland or small islands, cooking, gathering trepang from the reefs and smoking it for packing and export. These small family businesses were profitable enough to support everyone involved and maintain the boats and equipment.

Table 1 lists only those marriages between Filipinos and Torres Strait Islanders of non-Filipino descent mentioned in subsequent discussion. 11 of the wives are the daughters of European, Pacific Islander, Sri Lankan or West Indian fathers. A devastating series of introduced diseases, culminating in the 1875 measles epidemic, halved the original population of some $3000-3500 .{ }^{8}$ By the 1880 s the ethnic composition of the Torres Strait Islander population was significantly altered through intermarriage between local women and immigrants of diverse origin. Later marriages also took place between Filipinos and the Torres Strait-born daughters of Filipino fathers. These comprise arguably a separate ethnological category and are listed in Table 2, again limited to the families referred to in the paper. Without statistical analysis I cannot say how this rate compares with other immigrant groups but I assume such marriages were encouraged, even actively initiated, by the woman's father on cultural and religious grounds, since he generally decided his children's marriage partners.

7 Queensland Legislative Assembly Votes and Proceedings 1896, Annual report of the Government Resident, Thursday Island 1894-1895: 2.

8 Mullins 1992. 
Table 1: Filipino men with Indigenous wives (Aboriginal wives marked with an asterisk)

\begin{tabular}{|c|c|c|c|c|c|}
\hline Name & Dates & Birthplace & $\begin{array}{l}\text { TS/ } \\
\text { Aboriginal } \\
\text { wife }\end{array}$ & Dates & Birthplace \\
\hline BLANCO, Juan & c1864-1911 & Capiz & $\begin{array}{l}\text { *Annie } \\
\text { DUPAR }\end{array}$ & c1878-1945 & Escape River \\
\hline CANENDO, Matteo & c1854-1922 & Leyte & $\begin{array}{l}\text { *Katie } \\
\text { WANTO }\end{array}$ & c1870-1920 & $\begin{array}{l}\text { Cape } \\
\text { Grenville }\end{array}$ \\
\hline $\begin{array}{l}\text { CARABELLO, } \\
\text { Thomas }\end{array}$ & $1848-1935$ & Cebu & Morabisi & c1871-1920 & Yam Island ${ }^{1}$ \\
\hline $\begin{array}{l}\text { CADAUS, } \\
\text { Augustino }\end{array}$ & c1860-1952 & Santa Iloco & $\begin{array}{l}\text { Lavinia } \\
\text { WARE }\end{array}$ & c1887-1924 & Yam Island \\
\hline DELACRUZ, Lopez ${ }^{2}$ & c1876-1915 & Manila & $\begin{array}{l}\text { Anna } \\
\text { RANDOLPH }\end{array}$ & c1884-1964 & $\begin{array}{l}\text { Nepean } \\
\text { Island }\end{array}$ \\
\hline $\begin{array}{l}\text { DELGARDO, } \\
\text { Isidoro }\end{array}$ & $1860-1940$ & Algal & $\begin{array}{l}\text { Guni Maria } \\
\text { Louisa }\end{array}$ & c1868- & Yam Island \\
\hline FABIAN, Gregorio & c1853- & Capiz & $\begin{array}{l}\text { Kuruwara } \\
\text { Philomena } \\
\text { KADOBA }\end{array}$ & c1864-1933 & $\begin{array}{l}\text { Two Brothers } \\
\text { Island }\end{array}$ \\
\hline $\begin{array}{l}\text { FRANCIS, Juan } \\
\text { (Johnny) }\end{array}$ & c1853-1925 & Capiz & $\begin{array}{l}\text { Yadh Ellen } \\
\text { GARCIA }\end{array}$ & & $\begin{array}{l}\text { Coconut } \\
\text { Island }\end{array}$ \\
\hline $\begin{array}{l}\text { FRANCIS, Juan } \\
\text { (Johnny) }\end{array}$ & c1853-1925 & Capiz & $\begin{array}{l}\text { Lenwath } \\
\text { Nellie } \\
\text { MATAU }\end{array}$ & c1881-c1914 & Skull Island \\
\hline $\begin{array}{l}\text { FRANCIS, Juan } \\
\text { (Johnny) }\end{array}$ & c1853-1925 & Capiz & $\begin{array}{l}\text { Uludh } \\
\text { Patagam } \\
\text { GARIBA } \\
\text { IKUL }\end{array}$ & c1874-1930 & Skull Island \\
\hline GALORA, Pedro & c1840-1920 & San Aciento & $\begin{array}{l}\text { Clara } \\
\text { GONELAI }\end{array}$ & c1866-1909 & Jervis Island \\
\hline GARCIA, Andrew & & & Yadh Ellen & & Skull Island \\
\hline GUIVARRA, Pedro & c1867-1899 & Masbate & $\begin{array}{l}\text { Wazan Annie } \\
\text { PITT }\end{array}$ & $1881-1933$ & $\begin{array}{l}\text { Murray } \\
\text { Island }\end{array}$ \\
\hline LLOREN, Magno & c1881- & Leyte & $\begin{array}{l}\text { Felicia } \\
\text { Magdalina } \\
\text { PITT } \\
\text { LOSBANES }\end{array}$ & c1886-1912 & $\begin{array}{l}\text { Halfway } \\
\text { Island }\end{array}$ \\
\hline LOHADO, Antonio & c1868-1918 & Antique & Nancy SAKI & c1871-1916 & Burke Island \\
\hline LOSBANES, Cyriaco & c1878- & Iloilo & $\begin{array}{l}\text { Felicia } \\
\text { Magdalina } \\
\text { PITT }\end{array}$ & c1886-1912 & $\begin{array}{l}\text { Halfway } \\
\text { Island }\end{array}$ \\
\hline $\begin{array}{l}\text { MONMARILE, } \\
\text { Firmino }\end{array}$ & c1877- & $\begin{array}{l}\text { Lingayan, } \\
\text { San } \\
\text { Fernando }\end{array}$ & $\begin{array}{l}\text { Margaret } \\
\text { Mary }\end{array}$ & c1886- & Yam Island \\
\hline RAVINA, Pedro & $1862-$ & Zambales & Siau LIFU & c1884-1911 & $\begin{array}{l}\text { Darnley } \\
\text { Island }\end{array}$ \\
\hline REMIDIO, Pablo & c1865-1941 & Vigan & $\begin{array}{l}\text { Caroline } \\
\text { Maria LIFU }\end{array}$ & c1871-1902 & $\begin{array}{l}\text { Murray } \\
\text { Island }\end{array}$ \\
\hline
\end{tabular}




\begin{tabular}{|l|l|l|l|l|l|}
\hline Name & Dates & Birthplace & $\begin{array}{l}\text { TS/ } \\
\text { Aboriginal } \\
\text { wife }\end{array}$ & Dates & Birthplace \\
\hline ROAS, Ramon & c1856-1926 & Zamboanga & $\begin{array}{l}\text { Kias Mary } \\
\text { Ann }\end{array}$ & c1866-1940 & Banks Island \\
\hline SPAIN, Claudio & c1868-1928 & Marianas & Jane & $c 1872-1912$ & $\begin{array}{l}\text { Darnley } \\
\text { Island }\end{array}$ \\
\hline SUECO, Sabelo & c1862-1902 & Cebu & $\begin{array}{l}\text { Mary } \\
\text { WALTON }\end{array}$ & $1871-1918$ & $\begin{array}{l}\text { Warrior } \\
\text { Island }\end{array}$ \\
\hline
\end{tabular}

${ }^{1}$ Although Morabisi's birthplace is recorded as Yam, she was the daughter of a Sri Lankan seaman and Konai from Darnley Island; she is elsewhere referred to as a 'halfcaste', Kemuel Kiwat, pers comm, 1996.

${ }^{2}$ Descendants took the surname 'Lopez'.

${ }^{3}$ Descendants anglicised their surname to 'Raymond'.

Table 2: Filipino men with Torres Strait Islander wives of Filipino descent

\begin{tabular}{|l|l|l|l|l|l|}
\hline Name & Dates & Birthplace & TS-Filipino wife & Dates & Birthplace \\
\hline $\begin{array}{l}\text { DORANTE, } \\
\text { Santiago }\end{array}$ & c1865-1948 & Samar & $\begin{array}{l}\text { Wasada } \\
\text { NAPOLEON }\end{array}$ & c1887-1945 & $\begin{array}{l}\text { Murray } \\
\text { Island }\end{array}$ \\
\hline $\begin{array}{l}\text { IRLANDES, } \\
\text { Raymundo }\end{array}$ & $1896-$ & Leyte & $\begin{array}{l}\text { Victorina (Nina) } \\
\text { LOPEZ }\end{array}$ & $1902-$ & $\begin{array}{l}\text { Thursday } \\
\text { Island }\end{array}$ \\
\hline KANAK, Joseph & c1866-1939 & Guam & $\begin{array}{l}\text { Raphaela } \\
\text { FRANCIS }\end{array}$ & c1898- & $\begin{array}{l}\text { Darnley } \\
\text { Island }\end{array}$ \\
\hline LLOREN, Magno & c1881- & Leyte & $\begin{array}{l}\text { Luisa } \\
\text { CARABELLO }\end{array}$ & $1902-$ & $\begin{array}{l}\text { Darnley } \\
\text { Island }\end{array}$ \\
\hline REMIDIO, Pablo & c1865-1941 & Ilocos & $\begin{array}{l}\text { Nicolossa } \\
\text { HIERONYMO } \\
\text { MORALES }\end{array}$ & $1885-$ & $\begin{array}{l}\text { Banks } \\
\text { Island }\end{array}$ \\
\hline $\begin{array}{l}\text { SABATINO } \\
\text { Nicholas }\end{array}$ & $1871-1948$ & Iloilo & $\begin{array}{l}\text { Johanna } \\
\text { LOHADO }\end{array}$ & $1898-$ & $\begin{array}{l}\text { Darnley } \\
\text { Island }\end{array}$ \\
\hline $\begin{array}{l}\text { SIM, Eustacio } \\
\text { c1864-1931 }\end{array}$ & Panay & $\begin{array}{l}\text { Maria Eusebia } \\
\text { GALORA }\end{array}$ & $1889-$ & $\begin{array}{l}\text { Thursday } \\
\text { Island }\end{array}$ \\
\hline $\begin{array}{l}\text { XEROMENES, } \\
\text { Domingo }\end{array}$ & c1874-1914 & Cebu & Eleanora ROAS & c1889-1939 & $\begin{array}{l}\text { Thursday } \\
\text { Island }\end{array}$ \\
\hline
\end{tabular}

Women traditionally married young, soon after puberty, and there can be a considerable age difference between husband and wife. Ages are generally approximate but among the Filipino-Torres Strait Islander wives for whom we have recorded birthdates, the youngest was Maria Eusebia Galora, who married Eustacio Sim, then 24, when she was just 13 years and 11 months old; Eleanor Roas was 15 when she married Domingo Xeromenes aged 30. Another marked trend is the number of marriages among the children of Filipinos seen in the Blanco, Bullio, Canendo, Dorante, Elarde, Garcia, Guivarra, Irlandes, Kanak, Lopez, Manantan, Pasquale, Raymond (Roas), Remidio, Sabatino and Sueco families. 
During the early years, there were relatively few constraints on the young men's movements and sexual relationships must have been common with women on the islands close to the pearling grounds. Before 1884, however, the only negotiation was with the woman herself and her kinfolk. The authorities labelled these unregistered unions 'prostitution' and suspected the men of entering into them for the basest of motives. In 1901 the state began to interfere in marriages between Indigenous women and non-Indigenous men: under section 9 of the Aboriginals Protection and Restriction of the Sale of Opium Acts 1897-1901, they could not marry without written permission from the chief protector, acting on advice from the local protector. The then chief protector, however, took the enlightened position that, since it was 'a practical impossibility to prosecute all the men - Europeans, Asiatics, and [Pacific] Islanders - living with aboriginal females, under the harbouring clauses of the Act', he encouraged marriage 'rather than lay my department open to the reproach of sanctioning concubinage and prostitution'. ${ }^{9}$

This original tolerance (though not approval) of interethnic marriage was overtaken by a growing ideological commitment to 'racial purity' and a revulsion from 'miscegenation', which swept the Anglo-Germanic world (including Australia) during the interwar years. The local protector sought to extend his control over the marriages of the previously exempt 'half-castes' of Thursday and adjacent non-reserve islands, including the children of Filipino-Indigenous marriages, who were technically 'Australian-born Filipinos'. In the early 1920s Santiago Remidio (Filipino father and New Caledonian-Murray Island mother), was refused permission to marry Nazareth Ansey (Rotuman father and Rotuman-Murray Island mother) unless both became permanent residents of Murray Island and Santiago agreed to relinquish his 'unprotected' status and become 'subject to full departmental control as a native'. ${ }^{10}$ There was, however, no attempt to control the Filipino-European children or others of mixed Filipino heritage.

\section{Land tenure in the outer islands}

Land and kinship are the interlinked foundations of Torres Strait Islander traditional society: both were necessary for survival and both continue to be a source of conflict. Among issues raised during the native title claim process were the ownership/custodianship distinction and the status of unwritten agreements giving immigrant heads of families in the outer islands rights of access to and use of another's land. Surviving documents, as well as oral accounts by descendants and others, throw light on such issues and, despite their disparate provenance and viewpoints, confirm each other in many details. In addition to agreements allowing an outsider to build a house and establish a garden on a particular

9 Queensland Parliamentary Papers 1906, 'Annual report of the Chief Protector of Aboriginals 1905': 15 .

10 Chief Protector of Aboriginals to Protector of Aboriginals, Thursday Island, 29 May 1923, Queensland State Archives [hereafter QSA] A/58773. 
piece of land in exchange for money or goods, families might equally well establish themselves on land inherited by the wife from either parent, which was then passed to her children. However, while the occupational, special or informal leases granted by the authorities for specific purposes were officially registered, informal land tenure agreements generally went undocumented. ${ }^{11}$ Some Filipino-heritage families complain of being disinherited by the native title process but the settling of most Torres Strait claims means that evidence can be considered more dispassionately and in a less litigious environment than previously. The following case studies illustrate the family context in which land transfer was negotiated and the limitations of unwritten agreements and inherited memories.

\section{Eastern islands}

Murray, Darnley, Stephens and Nepean Islands comprise the eastern islands, inhabited by the Miriam people originally from the Kiwai region of New Guinea. Foreigners who married local women lived on their wives' land and children born on the island were considered to have certain rights to small parcels of land. The nature and extent of those rights, however, are strongly contested. Pablo Remidio and Juan Blanco and their families lived for a period at Murray Island on their wives' estates: Caroline Maria Remidio inherited land from her mother and the Blancos presumably lived on land owned by the family of Annie's first husband, a Murray Islander named Ned Dupar. Santiago Remidio, born in 1888 at Murray Island, inherited a portion of land at Mas from his mother. On 5 July 1924 he officially made Sagigi caretaker during his absence. On 15 November 1924 Epseg, appointed caretaker for Caroline's land, Gazir, when she left the island, officially handed back the land to Santiago, although he remained caretaker until the land was required. These agreements were signed by the parties, witnessed by the local schoolteacher and recorded by the Murray Island court. Further entries minutely describe the shape, extent and boundaries of the land. ${ }^{12}$

Darnley, Stephens and Nepean Islands were all settled from Murray Island. They are intervisible, tiny Nepean lying between larger Darnley and smaller Stephens Islands. In 1885, after the removal of Pacific Islanders from Murray to Darnley Island, the Indigenous population became a minority, although they retained almost all of the land. After the discovery of the 'Darnley Deeps' shell beds in 1893, Darnley became a centre for pearling operations and for about a decade hosted a small Filipino community. Giving evidence into the death of Cyriaco Losbanes, in December 1903, Juan Blanco stated 'plenty my countryman there'. ${ }^{13}$ They included Blanco himself, Thomas Carabello ('Thomas Manilla'), Louis Castro ('Louis Manilla'), Juan Francisco Garcia (Johnny Francis), Pedro Guivarra, Joseph Kanak, Magno Lloren, Cyriaco Losbanes, Pedro Ravina, Sabelo

11 For example, land for a bêche-de-mer or pearling station could be granted under section 10 of the Pearlshell and Bêche-de-Mer Fishery Act 1881.

12 Murray Island court records 1924; Colin Sheehan, pers comm, 2003.

13 Inquest into death of Ceriaco Losbanes, QSA JUS/N317/384/03. 
Sueco and their families. Most of them left for Thursday or Horn Islands during various closures of the beds but others remained. The children of Thomas Carabello and the Dane, Thomas Randolph, grew up with the Pau children at Sebeu, part of Isem on Darnley Island, on Pau family land. ${ }^{14}$

In August 1982, a few months after Koike Mabo launched his eponymous court case, Joseph Sabatino spoke to me about the land belonging to his grandfather, Joseph Kanak, at Darnley Island, which was being used by Charlie Gela. He explained that, because he and his wife had moved to the Hammond Island Roman Catholic mission after their marriage in 1954, they had lost that land. Land was under the control of the council and could not be sold. ${ }^{15}$ He was referring to Egriu 'Village', which Francis leased from the biggest landowner, the mamus ('chief') Bogo Pilot. According to descendants, Francis gave Egriu to his daughter, Raphaela, after her marriage to Joseph Kanak but handwritten letters from Francis to the chief protector indicate that the agreement with Pilot was in the nature of a lease rather than a purchase: in the first, he writes 'I rent the ground from Mamouse and in Darnley for 20 years'; in the second that 'the agreement is up now, with me and Bogo and he hand over this property to my daughter Rafila'. ${ }^{16}$

Joji Ohshima, leader of a Japanese ethnographical research team to the strait in the late 1970s, relates the history of ownership of 'Village Z' on Darnley Island. He chose to study land, because it 'is the most important asset of Darnley Islanders and land tenure indicates how island social relationships work' and because, in this particular village, 'the history of land ownership and inheritance of land is relatively clear'. Although he names neither the place nor the individuals concerned, it is possible, from information from the families concerned, to reconstruct the relevant early sequence of events. I have inserted names and dates in square brackets.

Up to about one hundred years ago the area where Village Z [Egriu] is now located belonged to a native Erub Island man [Bogo Pilot]. Around 1900-1910 a Filipino fisherman [Johnny Francis] bought a block of that land for $£ 50$, married a woman of Erub [actually from Skull Island] and lived there. The couple had a daughter [Raphaela] and they gave the land to her and moved to Auridh [Skull Island]. That daughter has since moved to Hammond Island, so she married out [to Joseph Kanak]. She gave the ownership to a friend, P [Charlie Gela], who lived in Keriam Village on the north side of the island, which is now abandoned. P took his children and nephews and moved to Village Z. It was at that time when Christian missionaries were coming into the area [1915]. ${ }^{17}$

14 The connection was through Eti, the Pau family ancestor, whose sister, Konai was the maternal grandmother of the Carabello and Randolph children, Kemuel Kiwat, pers comm, 1996.

15 Joseph Sabatino, pers comm, 1982.

16 John Francis to Chief Protector of Aboriginals, 17 November 1911 and 8 June 1915, QSA A/58658.

17 Ohshima 1983: 495. Ohshima must be referring to the handover from the London Missionary Society to the Church of England in 1915. Margaret Lawrie was told in the 1960s that the owner 
However, the local protector had the power to ignore such agreements and send any immigrant-headed family away from a reserve island. This was supposedly the case for Guam-born Joseph Kanak, who, his family claim, was evicted from Darnley Island to Hammond Island 'for inciting the natives' and asked the Gela family to caretake the land. ${ }^{18}$ In 1915 Kanak left the diving fleet after his marriage to the convent-educated Raphaela Francis and the couple made their home at Egriu, Raphaela's birthplace, where their first seven children were born. ${ }^{19}$ Kanak served as a local policeman for the next 15 years while also tending his gardens, which 'were at once the pride and envy of the natives and half-castes' ${ }^{20}$ There is no written evidence that Kanak was evicted from Darnley Island but the authorities certainly kept an eye on outer island 'half-caste' families for signs of dissent. The Kanak family's decision to relocate to Hammond was probably prompted more by the priest's urging, the prospect of freedom from government 'protection' and regular access to the sacraments, the promise of good land for gardening and closeness to their two daughters who were then boarders at the Thursday Island convent.

As to Stephens Island, it had lost most of its Indigenous population by the late 19th century, when 'Claudio Spain', a whaler from the Marianas, took a Darnley Island woman, Jane, to live there with him. Claudio died on the island in 1928. He and Jane had a daughter, who married a son of Bogo Pilot, and two sons, one of whom took the surname 'Cloudy', the other 'Stephen' after the name of the island. Nepean Island was uninhabited when Bogo Pilot permitted Santiago Dorante to settle there with his family. It is said that the argumentative Dorante originally settled on Darnley Island, where several of his nine children were born, but came into conflict with local residents and Pilot may have leased him Nepean to avoid further confrontations and/or possibly through a relationship with his Murray Island wife, Wasada. ${ }^{21}$ Dorante family members moved away in the early 1930s, some to Stephens Island and others to the Hammond Island mission and the island is again uninhabited.

\section{Central islands}

Yam Island, near Warrior Reef, was another centre of pearling operations. When I lived there briefly in 1982, I was told that it was once the site of a small 'Malaysian' community and shown a 'Malaysian' child's grave. Juan Blanco's second child was also born on Yam Island (his first was born at Darnley Island) and the Cadaus, Delgardo and Sabatino families lived there for a considerable

of the fishtrap at Egriu was 'Francis (Manila man, Aurid)', Lawrie, Folder on eastern island fishtraps, MS MLC 1791-334, John Oxley Library (now Queensland Memory), State Library of Queensland.

18 Angie Ross Akee, pers comm, 1988.

19 His last entry as a holder of a man-in-charge licence is in February 1915, Register of men in charge licences, 1915-1957, QSA SRS721/1.

20 Annals of Our Lady of the Sacred Heart, 1 December 1939: 415.

21 Alma Pilot, pers comm, 2008. 
time. At Yam Island in September 1931, Fr Doyle gave communion to three 'old Manila men', possibly Augustino Cadaus, Isidoro Delgardo and Nicholas Sabatino. 22

Cadaus had married a Yam Island-born woman, Lavinia (Nellie) Ware, the daughter of a New Caledonian fisherman and a Yam Island woman in a Catholic ceremony in 1906, and their two daughters were born at Yam. Cadaus, who worked as a tender and trepanger, is described in one record as 'half Filipino', which usually indicates that his father was Spanish. He settled permanently on Yam Island with his two daughters and their families and died here in 1952, the last surviving Filipino settler.

The diver, Isidoro Delgardo, married another Yam Island woman, Guni Maria Louisa, again in a Catholic ceremony on Thursday Island in 1890. Their child, Francesca, was baptised on 9 June 1886, suggesting that the couple had been together since at least 1885 and through that relationship Delgardo would have had rights to settle on his wife's land. ${ }^{23}$ There appear to be no surviving children and Delgardo eventually moved away to Hammond Island.

Iloilo-born Nicholas Sabatino married Johanna Lohado, the daughter of a Filipino father and Burke Island-born mother. Their first child was born at nearby Warrior Island, five subsequent children at Yam (one being Nicholas Florentino, whose grave was shown to me as evidence of the island's 'Malaysian' community), and the last two at Hammond Island. His descendants claim that Sabatino was given land at Yam by the traditional landowner, Baluz, in recognition of the close (possibly sibling) relationship between his wife's mother and Johanna's grandmother. Johanna's grandsons explained that her land is located on the shoreline and the almond tree she planted as a marker is still there. ${ }^{24}$ At least two of her children, Florentino and Mary, were born under that tree and we may assume that their placentas are buried there, as required by custom. There was once an old bêche-de-mer pot on the shore but it has been replaced by a store, fish factory and fuel depot. Neither of Johanna's surviving children were acknowledged as having rights to the land, the council explaining that land on the island was scarce and that, being women and no longer residents, they did not have to be consulted.

Unlike Yam Island, the other small central islands were not major pearling centres but Skull Island was for many years home to the renowned diver, Johnny Francis ('Francis Cranky') from Capiz. ${ }^{25}$ The island had supported an Indigenous population in the mid-1830s but was uninhabited when the ni-Vanuatu Matau and two countrymen took an occupation lease over it early in the 20th century. ${ }^{26}$ Lenwath Nellie, one of Matau's children by Yarka from Skull Island, was

22 Deere 1994: 23.

23 Algal may be a suburb of Manila or possibly 'Algar', a Spanish place name. Francesca's birth was not officially recorded.

24 Ambrose Bin Juda and Bora Bin Juda, pers comm, 2005.

25 Francis arrived in Torres Strait in 1884. Kranki means 'crazy' in Torres Strait Creole.

26 Queensland Pearl-shell and Bêche-de-mer Commission 1908: 268. 
Francis' second wife. ${ }^{27}$ Francis and his third wife, Uludh Patagam, moved to Darnley Island around 1895, possibly for their children's schooling. ${ }^{28}$ The chief protector had given Francis written permission to stay on Skull Island 'for life' on 6 September 1889 but in 1911 the new protector refused to allow Francis to return to Skull Island from Darnley, because the islands were about to be proclaimed Aboriginal reserves. ${ }^{29}$ However, Francis and Uludh did return after his daughter's marriage to Joseph Kanak. The Anglican priest, Rev MacFarlane, described their life there in 1925, not long before his death, in a 'composite ironand-coconut-leaf dwelling'. From his three central island-born wives Francis

has inherited some family estates. But as far back as the [18]80s he was given permission by the then Administrator, the late Hon. John Douglas, to settle there, and with scrupulous care preserves the documents giving him the right of residence. Wrapped in old official envelopes and tied with thick cord, Johnny is confident that they are quite safe stowed away in a worn-out leather schoolbag. His will is there also, as well as his papers of naturalisation and some fishing licenses ... Just now he spends his days, hobbling along with the aid of a long stick, in planting coconut trees and making his garden. ${ }^{30}$

John Francis Kanak, who stayed with his elderly grandparents in the early 1920s, recalls that they

lived from their garden and Uludh made bread from coconut tuba [coconut wine]. They never felt hungry. There was lots of water and there was a plantation of coconuts and he also planted taro, sweet potato and corn. Uludh made yeast with tuba - her husband showed her how to do it and she made bread with it ... They ate a lot of fish and never wasted anything. Passing divers who knew him from the early days or by reputation would bring them rice and flour. Recognising Uludh's ownership of the island, visitors always asked her permission to anchor a boat or go onshore. ${ }^{31}$

Francis died on the island in June 1925. Uludh 'dressed him and put him inside the house and sat down outside to mourn. She made smoke signals to let her relations, who were trochus fishing near Roberts Island, know that something had happened to her husband. He was buried by hurricane lamplight and Uludh then went and sat outside in a small boat'. She was too fearful to remain on the island and resettled on nearby Yorke Island. When Joseph and Raphaela

27 There is no official record of Francis' marriage to Yadh from Skull Island, which may have occurred before 1884. Yadh was probably the mother of Cornelio Garcia, whom Francis raised as his son and whose father may have been a relation. Francis himself wrote that his three wives came from Skull Island.

28 John Francis to Chief Protector of Aboriginals, 8 June 1915, QSA A/58658.

29 Chief Protector of Aboriginals to John Francis, 11 October 1911, QSA A/58658.

30 MacFarlane 1925: 11.

31 Maria Johnson Gebadi, pers comm, 2000. 
Kanak moved to the Catholic mission at Hammond Island, they took the ailing Uludh with them. She died shortly afterwards at Thursday Island, where she is buried..$^{32}$

\section{St Joseph's Roman Catholic mission at Hammond Island (Keriri)}

The Hammond Island Catholic mission became the third Torres Strait community of predominantly Filipino character, when a number of outer island families exchanged departmental for church control and moved there after its opening in 1929. The mission was originally conceived of as a home for 'the Catholic halfcastes of Torres Straits', who, being emblematic of the local failure of the 'white Australia' policy, were proving an embarrassment to authorities.

Hammond Island belongs to the Kaurareg from south-west Torres Strait, who in 1922 were removed at gunpoint to Banks Island. The Catholic church then negotiated government permission for a mission station which would give its residents 'the opportunities of practising their religion' and 'their own homes with garden plots, [where they could] enjoy a measure of independence and detachment conducive to their general well being '. ${ }^{33}$ By late October 1928 Fr John Doyle had obtained a government grant and pledges from 'a few old Manila men' to settle there and train the young men 'to work the land, look after poultry etc' $^{\prime 34}$

The first applicant was Joseph Kanak, then aged about 65 and living with his family on Darnley Island. Persuaded by 'consideration of their present and future welfare', he set about transferring his home to the mission. ${ }^{35}$ The Sabatino and Dorante families followed, as later did the elderly widowers Pablo Remidio and Isidoro Delgardo, and the population grew to 130 before the 1942 evacuation. ${ }^{36}$ Other pre-war residents with Filipino connections include Annie Blanco and her third husband, the Aboriginal Bob Quetta; Annie's son and daughter-in-law, Silverio and Josephine Blanco; Annie Randolph Lopez with some of her children and their families; Alfonso and Marcellino Canendo and their wives. Only a minority of the original inhabitants returned after the war and the mission's pre-war Filipino character survives only in photographs and the memories of its residents.

\section{Contemporary identity}

Examples from three documents a decade apart demonstrate the changing legal classification of the wives and children of Filipinos. Until at least 1920, their

32 Maria Johnson Gebadi and Dulcie William, pers comm, 1999.

33 Annals of Our Lady of the Sacred Heart, 1 December 1939: 415.

34 Deere 1994: 17.

35 Annals of Our Lady of the Sacred Heart, 1 December 1939: 415.

36 Fr Tom Mullins, pers comm, 1988. 
status was unambiguous: when Luisa Carabello Lloren, the Darnley Islandborn daughter of a Filipino father and Yam Islander mother, left Australia with her Filipino husband and Thursday Island-born step-children in 1920, each was categorised as an 'Australian-born Filipino'. ${ }^{37}$ In 1912 the outer islands were designated as reserves and the children living there became 'Aboriginals', whereas those living on and around Thursday Island were increasingly known as 'Filipino half-castes', whatever the legal classification of their fathers, on the basis of their Indigenous maternal ancestry: in 1930 Gregorio Galora, son of the naturalised Pedro Galora, referred to himself as 'a half caste Filipino' ${ }^{38}$ On the mainland in 1941, however, Isabella Ravina, daughter of Pedro and Siau Ravina, is referred to as 'an Island girl' ${ }^{39}$

Stone's description of the wellsprings of political action could equally well be applied to the construction of personal identity:

The individual is moved by a convergence of constantly shifting forces, a cluster of influences such as kinship, friendship, economic interest, class prejudice, political principle, religious conviction and so on, which all play their varying parts and which can usefully be disentangled only for analytical purposes. ${ }^{40}$

The third and fourth generation, especially those born on the mainland and who are well-educated professionals, emphasise their Indigenous rather than Filipino family connections, which in many cases are barely remembered or acknowledged. Changing legislation and ideology have influenced their selfidentification: while aware of their Filipino ancestry, they grew up identifying as Torres Strait Islanders, more familiar with their maternal Indigenous heritage, knowing the Philippines only through inherited stories. They were enculturated not as Filipinos but as Torres Strait Islanders, surrounded from babyhood by extended kin, their only difference being their physical appearance, Catholic religion and familiarity with a repertoire of songs and (at that time) exotic dishes and musical instruments. With the exception of Dorante, Kanak and Sabatino, their names and stories are largely forgotten today, with daughters assuming the surnames, religion and 'custom' of their Torres Strait Islander husbands and sons remaining on the mainland post-war. Thus, Adam Lees, a descendant of Juan Blanco and a senior Indigenous Affairs Advisor at Mount Isa Mines, previously employed by the Department of Foreign Affairs and Trade, identifies himself only through his ancestral connections with 'Mer Island (Peibre Clan) and with the Indigenous people of Cape York Peninsula'. The Torres Strait Islander identity of Maria Dorante Mene, who works for the Queensland Health Department, lies in her knowing her unique place in the world. Secure in that

37 Certificates of Exemption from Dictation Test, NAA J2483 287/100, J2483 288/1, J2483 288/2, J2483 288/3, J2483 288/4.

38 Rex v Victoriano Blanco, Walter Busch and Casimero Manantan for assault, Circuit Court, Cairns, 1 April 1930, QSA A/28874.

39 Inquest into death of Milko Yovanov, QSA JUS/N1094/30/41.

40 Stone 1971: 65. 
identity, which is at times questioned by Indigenous clients, she tells me: 'When I cross the water from Horn Island to Thursday Island I know who I am and where I belong. ${ }^{41}$

\section{Conclusion}

The Filipino outer island settlers arrived in Queensland before federation, attracted to Torres Strait by employment opportunities and good wages. They came from great upheaval in their homeland to a no less turbulent Torres Strait, as its traditional society, religion, economy and politics were overwhelmed by an influx of foreigners. At a time of relatively free movement of people the Filipinos managed to exert a good deal of control over their lives before they and other 'coloured aliens' were targeted by economic, social, legal and administrative restrictions.

The men chose a different fate from the majority of their countrymen. By committing to a new home and immigrant identity among a different people, they were doubly exiled, a choice made less wrenching in places so geographically and topographically similar to their islands of origin (and by their frequent absences for work among compatriots). They all knew each other, with some connections being forged in the recruiting ports, others in the strait itself through shared work, recreation and worship. Despite the overwhelmingly Protestant character of the strait, they kept their Catholic religious faith, married their baptised Torres Strait Islander wives in the Thursday Island church and sent their locally-born children to the Thursday Island convent for education. They witnessed each other's marriages and became godparents to each other's children. Their children often intermarried.

The intangible legacy of the men and their families consists of stories, recipes and songs, the memories of older inhabitants and the skills in diving, tuba-production and music-making they passed on to their descendants and privileged others, as they did their first names and their parents' names. The Dorante family's tenure at Nepean has passed into local folklore: the fiery Santiago is said to have beaten his wife and, desperate to escape to the safety of her family, she swam through the shark-infested waters to Darnley Island. Wasada's totem was Beizam (Shark) and sharks formed a line on either side of her to keep her safe. The Filipinos' tangible legacy consists of graves in local cemeteries, coconut plantations Johnny Francis claimed to have planted 'a couple hundreds of Cocoanut' trees on Skull Island and elsewhere ${ }^{42}$ - fruit trees (pawpaw, banana, mango and pineapple), stands of bamboo and sisal hemp (to make 'Manila rope') and the first freshwater wells dug by Filipino divers and their crews. When they left their outer island homes, they generally sold their chickens, ducks and goats; their houses were torn down and any building materials of value, such as galvanized iron and nails, were salvaged for further building; their household gardens were

41 Adam Lees, pers comm, 2000; Maria Dorante Mene, pers comm, 2010.

42 J Francis to Chief Protector of Aboriginals, 20 December 1915, QSA A/58658. 
taken over by later residents or are now overgrown and untended, like Thomas Carabello's rice plantation on Darnley Island. Only some of their wells are still in use, among the few physical survivals of the Filipinos' decades-long sojourn in the outer islands of Torres Strait.

\section{Acknowledgements}

I am indebted to Angie Ross Akee, Alison Bell, Fr Scotty Bob, Ambrose Bin Juda (deceased), Bora Bin Juda, Rosemary Sabatino Bin Juda, Fr Anthony Caruana MSC, Dorothy Dorante, Francis Dorante, James (Jimmy) Dorante, Orepa Peter Dorante, Barbara Erskine, Kathy Frankland, Maria Johnson Gebadi, Mapoo Gela (deceased), David Lawrence Guivarra, Denise Guivarra, Francis Guivarra (deceased), Dolores Dicen Hunt, Florence Savage Kennedy, Charlene Kennedy Lee, Kemuel Kiwat, Lizzie Thaiday Lui, Maria Dorante Mene, Vonda Moar, Fr Tom Mullins, Eva Salam (Mingo) Peacock, Alma Pilot, Harry (Oroki) Pitt, Margaret Reid, Anastasia Kanak Ross, Joseph Sabatino (deceased), Veronica Dorante Sabatino, Lila Sebasio Reuben, Colin Sheehan, Henry Stephen, Michael Stubbins, Jim Thaiday (deceased), Dulcie Alfred William and James Williams.

\section{References}

\section{Primary sources}

Annals of Our Lady of the Sacred Heart, 1 December 1939, Sacred Heart Archives, 1 Roma Rd, Kensington, New South Wales.

Certificates of Exemption from Dictation Test for Lloren family 1920, files J2483 287/100, J2483 288/1, J2483 288/2, J2483 288/3, J2483 288/4, dated 4 April 1920, National Archives of Australia, Queensland Branch, Brisbane.

Lawrie, M nd, Folder on eastern island fishtraps, MS MLC 1791-334, John Oxley Library (now Queensland Memory), State Library of Queensland, Brisbane.

Queensland Legislative Assembly Votes and Proceedings 1896, 'Annual Report of the Government Resident, Thursday Island 1894-1895', Queensland Government Printer, Brisbane.

Queensland Parliamentary Papers 1906, 'Annual Report of the Chief Protector of Aboriginals 1905', Queensland Government Printer, Brisbane. 
Queensland State Archives (QSA)

Queensland Circuit Court, Cairns 1930, Evidence from Rex v. Victoriano Blanco, Walter Busch and Casimero Manantan for assault, 1 April 1930, A/28874, QSA, Brisbane.

John Francis to Chief Protector of Aboriginals, 17 November 1911 and 8 June 1915, A/58658, QSA, Brisbane.

Chief Protector of Aboriginals to John Francis, 11 October 1911, QSA A/58658.

Chief Protector of Aboriginals to Protector of Aboriginals, Thursday Island, 29 May 1923, A/58773, QSA, Brisbane.

Queensland Justice Department inquest file into death of Ceriaco Losbanes held 7 December 1903 at Thursday Island, file JUS/N317/384/03, QSA, Brisbane.

Queensland Justice Department inquest file into death of Milko Yovanov held 10 January 1941 at Mossman, file JUS/N1094/30/41, QSA, Brisbane.

Thursday Island Court House 1915, Register of men in charge licences, 19151957, entry for Joseph Kanak dated 2 February 1915, file SRS721/1, QSA, Brisbane.

\section{Secondary sources}

Austin, M 1992, The Quality of Life: A Reflection of Life in Darwin During the Postwar Years, Maisie Austin, Darwin.

Bach, JPS 1955, The Pearling Industry of Australia: an Account of its Social and Economic Development, Department of Commerce and Agriculture, Canberra.

Chase, AK 1981, 'All kind of nation: Aborigines and Asians in Cape York Peninsula', Aboriginal History 1: 6-15.

Cubillo-Carter, I 2000, Keeper of Stories: Delfin Antonio Cubillo, Inez Cubillo Carter, Alice Springs.

Deere, TC 1994, Stone on Stone: Story of Hammond Island Mission, Our Lady of the Sacred Heart Roman Catholic Church, Thursday Island.

Dupeyrat, A 1935, Papouasie: Histoire de la Mission (1885-1935), Dillen, Paris.

Hennessy, NB 2004, A Journey in Antipodean Land: The Filipino Heritage in Australia, Seaview Press, Henley Beach, South Australia. 
Ileto, RC 1993, 'Philippine Australian interactions: the late nineteenth century', in Discovering Australasia: Essays on Philippine-Australian Interactions, RC Ileto and R Sullivan (eds), James Cook University of North Queensland, Townsville: $10-46$.

- 2004, 'Heriberto Zarcal: the first Filipino-Australian', in Navigating Boundaries: the Asian Diaspora in Torres Strait, A Shnukal, G Ramsay and Y Nagata (eds), Pandanus Books, Canberra, 123-137.

Jennings, K 2010, 'Everywhere and nowhere: [edited version of] the 2010 Ray Mathew lecture', The National Library Magazine, December 2010: 23-26.

MacFarlane, WH 1925, 'When shadows lengthen, yarns of the old identities of Torres Strait islands: a call at Aureed', The Queenslander, 30 May 1925: 11.

Mullins, S 1992, 'Torres Strait's pre-colonial population: the historical evidence reconsidered', Queensland Archaeological Research 9: 38-42.

Nailon, B 2005a, Emo and San Salvador. Book 1: Broome and Beagle Bay, Brigidine Sisters, Echuca.

- 2005b, Emo and San Salvador. Book 2: Cygnet Bay, Drysdale River and Lombadina, Brigidine Sisters, Echuca.

- and F Huegel (eds) 2001, This is your Place: Beagle Bay Mission: Birthplace and Cradle of Catholic Preserve in the Kimberley, new edition, Beagle Bay Community, Broome.

Ohshima, J (ed) 1983, Toresu Kaikyo no hitobito: People of the Torres Strait, Kokon Shoin, Tokyo.

Puertollano, K 2008, 'Filipino history in Broome', Kasama 22(3), July-September: 9.

Queensland Pearl-shell and Bêche-de-mer Commission 1908, 'Report of the Royal Commission', Queensland Government Printer, Brisbane.

Ruiz Wall, D and D Hunt 2008, 'Filipinos' contributions honoured in Broome's 39th Shinju Matsuri Festival', Kasama 22(3), July-September: 10-14.

Shnukal, A 2004, “"They don't know what went on underneath”: three littleknown Filipino/Malay communities of Torres Strait', Navigating Boundaries: The Asian Diaspora in Torres Strait, A Shnukal, G Ramsay and Y Nagata (eds), Pandanus Books, Canberra: 81-121.

Stone, L 1971, 'Prosopography', Daedalus 100: 46-79. 